\title{
Helmand Market Assessment
}

Submitted by:

Chemonics International Inc.

Submitted to:

Afghanistan Mission,

U.S. Agency for International Development

Kabul, Afghanistan

August 2003

USAID Contract No. 306-C-00-03-00502-00 


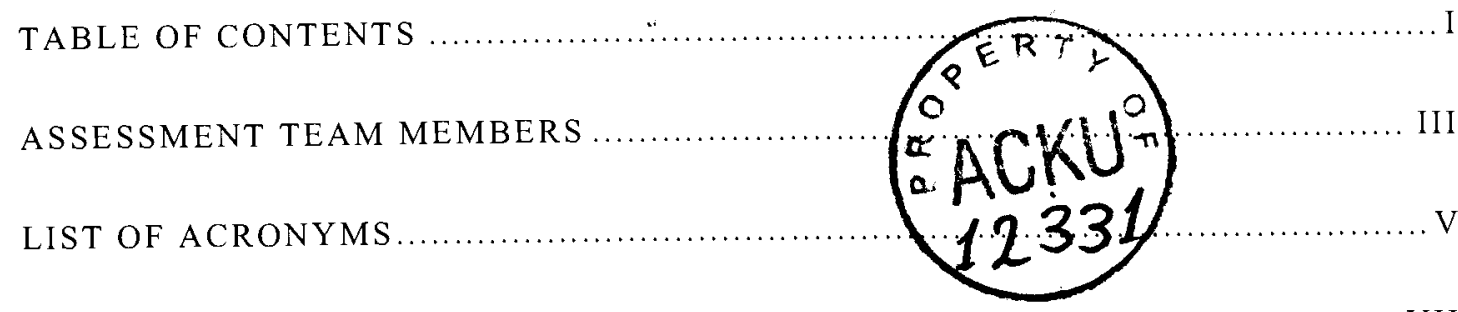

EXECUTIVE SUMMARY

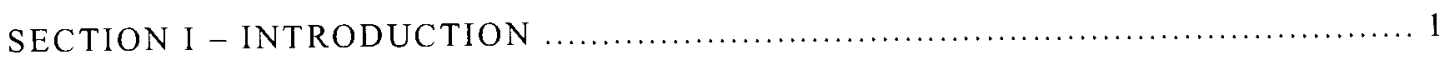
A. Background
B. Objectives of This Report
C. Organization of the Report

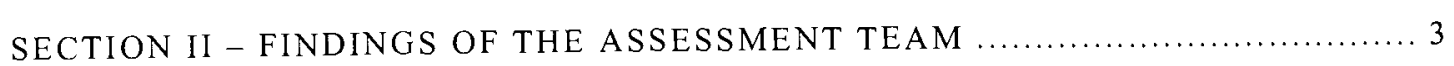

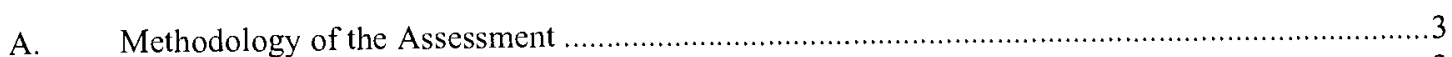

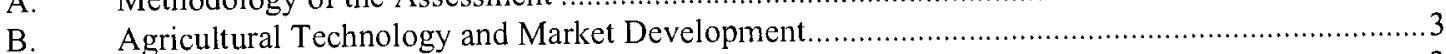

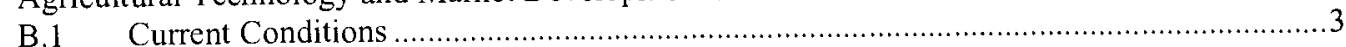

B.2 Participatory Rural Assessment of Local Markets ..................................................

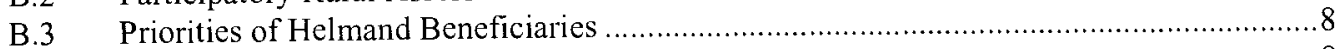

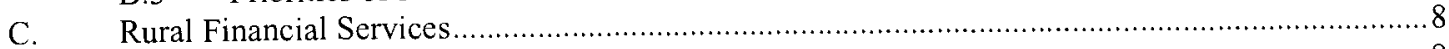

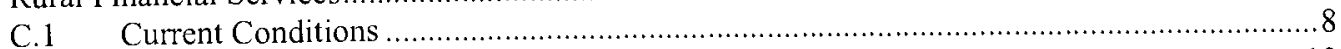

C.2 Priorities of Helmand Beneficiaries .............................................................. 10

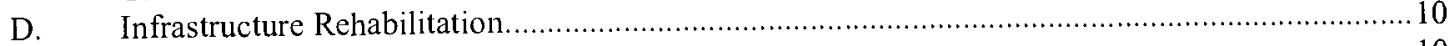

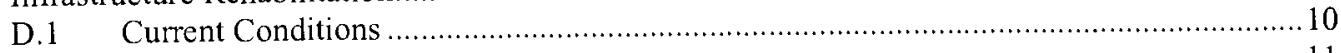

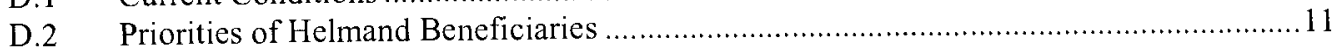

SECTION III - ASSESSMENT CONCLUSIONS ................................ 13

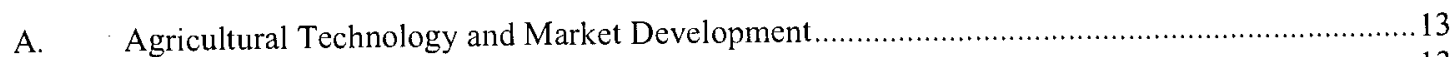

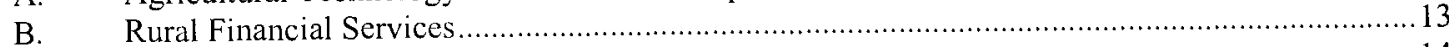

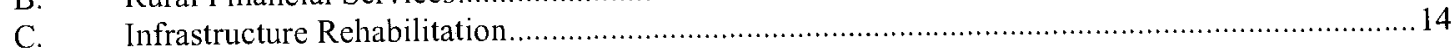

SECTION IV - ASSESSMENT RECOMMENDATIONS $\ldots \ldots \ldots \ldots \ldots \ldots \ldots \ldots \ldots \ldots \ldots . \ldots \ldots$

A. Agricultural Technology and Market Development......................................................... 17

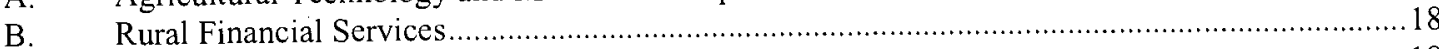

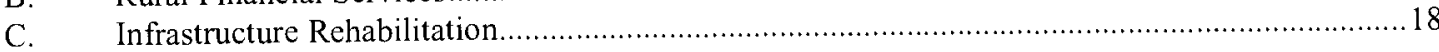

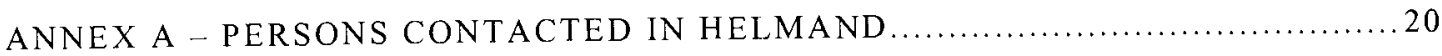

ANNEX B - HELMAND GOVERNOR'S LETTER TO MAAH $\ldots \ldots \ldots \ldots \ldots \ldots \ldots \ldots \ldots . \ldots \ldots \ldots$

ANNEX C - SUMMARY OF PARTICPATORY RURAL ASSESSMENT ...............26 


\section{ASSESSMENT TEAM MEMBERS}

Dr. Larry Morgan

Dr. Ken Neils

Frances Toomey

Nasir Wardak

Abdul Manan

Dr. Md. Nassiry
RAMP Chief of Party, Chemonics International

RAMP Chief Agricultural Strategist/Agricultural Economist, Chemonics International

RAMP Chief Rural Financial Services Advisor, Shorebank Advisory Services

Director, Seed Certification and Extension, Ministry of Agriculture and Animal Husbandry

Program Advisor/Afghanistan, International Center for Agricultural Research in Dry Areas (ICARDA)

Consultant, Food and Agriculture Organization of the United Nations 
REBUILDING AGRICULTURAL MARKETS IN AFGHANISTAN PROGRAM (RAMP) 


\section{Table of contents}

Babar Mumtaz G Kaj Noschis

Development of Kabul : Reconstruction and Planning issues

Fitroduction

$@ P J L$ SET RESOLUTION=600

@PJL ENTER LANGUAGE=PCL 
REBUILDING AGRICULTURAL MARKETS IN AFGHANISTAN PROGRAM (RAMP) 


\section{LIST OF ACRONYMS}

FAO Food and Agriculture Organization of the United Nations

MAAH Ministry of Agriculture and Animal Husbandry

RAMP Rebuilding Agricultural Markets in Afghanistan Program

REFS Rehabilitation of Economic Facilities and Services

SOW Statement of Work

TISA Transitional Islamic State of Afghanistan

UN United Nations

UNOPS United Nations Office of Project Services

USAID United States Agency for International Development 
REBUILDING AGRICULTURAL MARKETS IN AFGHANISTAN PROGRAM (RAMP) 


\section{EXECUTIVE SUMMARY}

A RAMP assessment team visited Helmand Province from August 10-14, 2003, to gain a fundamental understanding of the current agricultural situation and identify the agricultural priorities of the provincial government as well as beneficiaries of potential RAMP activities.

Helmand is a highly mechanized, highly irrigated province in Afghanistan. Although the agricultural sector has had a good production season, certain sub-sectors are having marketing problems. The marketing problems are exacerbated by the poor roads that make accessing distant markets difficult and expensive. The Helmand agricultural economy is closely linked to Kandahar and Herat as well as Quetta.

Farmers in Helmand expressed needs in a number of areas, including access to quality seeds, pest control, storage, market access, improved irrigation, improved roads, improved animal health, and access to credit for operating capital.

Helmand has an estimated 236,555 hectares of irrigated land, 4,168 hectares of rainfed land, and over 5000 hectares of land with orchards. Approximately 74,000 hectares of wheat was cultivated on irrigated land in Helmand in 2002/03 (FAO, NCOA, 2003). The total production of wheat in 2003 in Helmand Province was estimated by FAO at 211,000 mt.

Project Prioritization - To advance the agricultural sector and improve agricultural incomes and marketing opportunities, the following is recommended:

- The road from Lashkargah to the main Kandahar-Herat highway needs to be improved

- A comprehensive assessment of the irrigation system has to be a priority for determining precise irrigation rehabilitation job order statements of work, and the implications of that rehabilitation on Helmand agricultural production, particularly in the cotton subsector

- To assist farmers in identifying the quality of seed they need for increasing productivity of grains and legumes, extension agents of CADG and the MAAH in Helmand need to be trained

- Private seed multiplication efforts by farmers assisted by Mercy Corps and CADG need to be further supported

- Farmers need to be trained in the use of agricultural chemicals on their crops.

- At least one demonstration plot needs to be established in each cluster of villages in all Districts to show farmers the production potential of improved varieties of major crops, such as, wheat, rice, and maize

- Provide water control and management training to mirabs responsible for extensive irrigation schemes

- Provide technical assistance to farmers interested in installing greenhouses for vegetable production in the off season

- Farmers and traders need training in grain postharvest storage and handling. Grain storage (and drying) facilities that match the needs of farmers and traders need to be identified and installed before the bulk of the rice is harvested

- Grain, legume, and cumin cleaning and sieving equipment for farmers and traders need to made available on a custom basis

- Technical training of farmers, traders, and mill operators is needed in wheat grading using a sampling mill and other mechanical devices 
- The feasibility of modular wheat milling technologies, such as the Kice mill, needs to be made; if deemed feasible, investors for the milling equipment need to be identified

- Detemine the feasibility of peanut oil pressing and tomato ketchup processing

- Equipment for dehusking and separating mung beans for increasing the value of the beans need to be identified and the feasibility made

- Advocate for eliminating the government policy that limits cotton ginning to government owned gins

- Establish private nurseries for vegetables, tree crops, and other trees for reforestation

- Determine the feasibility of installing animal health laboratory facilities in the private sector

- Train and certify para-veterinarians in animal health, including vaccinating, disease and parasite control and treatment measures

- Establish an artificial insemination program through the MAAH and the para-vet program

- RAMP will coordinate with MISFA and MRRD to invite any of the pre-selected MFIs to work in Helmand province

- In collaboration with USAID, review the possibility of partnering with some entrepreneurs to create new agro-processors either directly or through a financial institution. 


\section{A. Background}

Chemonics International is assisting the U.S. Agency for International Development and the Ministry of Agriculture and Animal Husbandry (MAAH) in the implementation of the Rebuilding Agricultural Markets in Afghanistan Program (RAMP) during 2003-2006. The project aims to enhance food security and increase rural incomes in coordination with the MAAH's agricultural development policy and budget. RAMP has two main objectives: a) increased agricultural productivity and output, and b) increased incomes through effective linkages between producers, processors and markets.

To increase productivity and output, RAMP will address constraints imposed by the lack of cash resources for productive activities and deteriorated rural infrastructure. At the same time, RAMP will initiate rural infrastructure rehabilitation activities that would not be appropriate to carry out through either food for work or cash for work programs. To a lesser extent, the program also will support the expansion of the knowledge and use of improved technologies (new varieties, fertilizers, crop management and protection practices, equipment and machinery) through extensive field demonstrations, information dissemination, and efforts to develop the capacity of private sector input dealers to meet farm demand.

During the mobilization of RAMP, market assessments will be conducted in priority regions to identify the market structure for key commercial clusters that have high potential for increased competitiveness. Results of these assessments will be used to design and implement technical assistance interventions that increase food security and rural income. A seven-member team (page iii) was assembled and deployed to Helmand during August 10-14, 2003.

\section{B. Objectives of This Report}

The objectives of this report are:

1. Assessment of the major agricultural commodity markets and identification of key constraints to increased food security and increased incomes among rural families engaged in those markets; and

2. Identification of priority projects that can be implemented as RAMP job orders to increase access to agricultural technology, expand priority commodity and associated input markets, expand access to rural financial services and rehabilitate rural infrastructure.

\section{Organization of the Report}

Section II describes the findings of the Team in the areas of agricultural technology and marketing and rural financial services. Information on the infrastructure situation in Helmand is limited in this report, as no RAMP engineers were in-country at the time of this assessment. A comprehensive infrastructure assessment for Helmand is forthcoming and will be presented separately.

Section III describes Team's conclusions, based on findings from interviews, available data and site visits. 
Section IV describes the Team's recommendations for RAMP initiatives in Helmand.

Annex A lists the key Helmand officials and.cooperators contacted by the Team.

Annex B presents a letter from the Helmand Deputy Governor to the Minister of Agriculture and Animal Husbandry, outlining the Helmand Provincial Government's development priorities for RAMP assistance.

Annex $C$ presents a summary of a participatory rural assessment was conducted in the five most populous districts by a survey team from Helping Afghan Farmers Organization (HAFO) during August 5-10, 2003. 


\section{A. Methodology of the Assessment .}

The team received generous assistance from the Central Asia Development Group (CADG), in arranging interviews and site visits.

The team visited the provincial administration and discussed agricultural market development priorities. An overview of the agricultural situation in Helmand was given, as well as an overview of interventions needed to rehabilitate the agriculture sector and improve the livelihoods of agricultural populations. Helmand officials stressed the importance of rehabiliating the irrigation system and repairing the $45 \mathrm{~km}$ road from Lashkargah to the Kandahar-Herat highway. After this meeting, the MAAH member of the assessment team, Mr. Wardak, consulted with provincial departmental staff and the governor's office to discuss assistance priorities that might be met by RAMP. After this discussion, the Helmand Governor sent a letter to the Minister of Agriculture and Animal Husbandry to emphasize the Helmand provincial government's concerns about RAMP assistance (Annex B).

The remainder of the time was spent conducting interviews to obtain the development priorities of the local government, farmers and traders in various districts, and identifying and observing road and irrigation infrastructure inadequacies. Field trips were made to farms in Nad Ali District and site visits were made to irrigation systems. Wheat, rice and produce traders were interviewed in local markets and bazaars in Lashkargah. During the week prior to the team's visit to Helmand, , a participatory rural assessment was conducted in the five most populous districts by a survey team from Helping Afghan Farmers Organization (HAFO). The results of this survey are summarized in Annex C.

\section{B. Agricultural Technology and Market Development}

\section{B.1 Current Conditions}

Helmand is a highly mechanized, highly irrigated province in Afghanistan. Although the agricultural sector has had a good production season, certain sub-sectors are having marketing problems. The marketing problems are exacerbated by the poor roads that make accessing distant markets difficult and expensive. The Helmand agricultural economy is closely linked to Kandahar and Herat as well as Quetta.

Wheat and barley are planted in Oct-Dec and rice, mung beans, cumin, chickpeas, and vegetables are planted in May-June following the wheat harvest. Maize, cotton, melons, and watermelon are planted in the spring before the wheat is harvested.

To get more land cultivated under irrigation schemes, strategic irrigation infrastructure needs to be rehabilitated. Also, some irrigation sites, such as, the Nad-I-Ali Land Development Irrigation site, need to have additional drainage canals cleaned in order to allow the agricultural fields to drain properly. 


\section{Wheat}

Helmand has an estimated 236,555 hectares of irrigated land, 4,168 hectares of rainfed land, and over 5000 hectares of land with orchards. Approximately 74,000 hectares of wheat was cultivated on irrigated land in Helmand in 2002/03 (FAO, NCOA, 2003). The total production of wheat in 2003 in Helmand Province was estinated by FAO at $211,000 \mathrm{mt}$.

There are three classes of wheat supplied to the marketplace in Lashkargah. Approximately 33\% of the wheat is \#1 wheat, that is, the best wheat for making nan. The price of \#1 wheat since May 2002 ranged from Afs $3.8 / \mathrm{kg}$ ( $\$ 110 / \mathrm{mt}$ ) to Afs $12.2 / \mathrm{kg}$ ( $\$ 200 / \mathrm{mt})$. The selling price for \#1 wheat by the grain traders in Lashkargah was, on average, Afs $0.5 / \mathrm{kg}$ higher than the purchase price from farmers in 2003. Farmers are currently receiving about Afs $7.3 / \mathrm{kg}$ (US\$150/mt), slightly above the breakeven price.

The $2^{\text {nd }}$ class (about $35 \%$ of the total) of wheat does not produce as good a nan as \#1 class wheat. The average margin between first and second class wheat is about Afs $0.88 / \mathrm{kg}$.

The $3^{\text {rd }}$ class wheat (about $32 \%$ of the total) has been especially poor because of the infestation of the Sunn pest (stink bug). The average margin between $1^{\text {st }}$ class wheat and $3^{\text {rd }}$ class wheat is Afs $1.76 / \mathrm{kg}$. Some of the \#2 and much of the lower grade \#3 wheat is shipped to Pakistan, where it is milled and returned to Lashkargah as wheat flour. Traders, otherwise, are having a difficult time selling the \#3 wheat locally.

Storage of the relatively large supply of wheat is a problem for both farmers and grain traders. To store grains and pulses, farmers and grain traders use traditional storage facilities where pest control is difficult and postharvest losses are relatively high.

Relatively crude, diesel-powered, flour mills in Helmand mill the entire wheat grain without cleaning and sieving the grain first and without separating out the bran.

\section{Cotton}

In 2002, about 9,000 $\mathrm{mt}$ of cotton was produced on about 20,000 hectares of irrigated land in Helmand. About $5500 \mathrm{mt}$ of cotton was bought by the Bolan Company, a Government-owned organization, in Lashkargah, at a price ranging from Afs 8 to 10 per $\mathrm{kg}$. The Government purchase price was determined by the Ministry of Finance through an open tendering process. Farmers, who sold their cotton to the Government cotton gin, had an estimated net income of Afs 4290/ha. Private cotton ginners bought the remainder of the cotton from farmers at an average price of Afs $20.4 / \mathrm{kg}$. (Note: Although cotton is widely produced, the government continues to restrict all ginning of cotton to government-owned gins only. Despite the Government's policy against private sector operating a cotton gin, 44 private sector cotton gins with a capacity of $10,000 \mathrm{mt} /$ year are in operation.)

The total area of cotton production in 2003 is about $25 \%$ less than last year. The Governmentowned cotton gin will be purchasing cotton from farmers at a to-be-determined price. The gin still has $1400 \mathrm{mt}$ of cotton (in 180-kg bales that meet international standars), $120 \mathrm{mt}$ of cottonseed oil that is sold locally to shopkeepers for about Afs $35 / \mathrm{kg}$, and a minor amount of cottonseed that needs to be sold. 
Private cotton ginners sold the ginned cotton, about $32 \%$ of the original cotton, at a farm gate price of about Afs $53 / \mathrm{kg}$ to private traders from Pakistan. This price is above the international cotton price and may not be sustainable.

\section{Mung Bean}

Black mung bean and green mung bean are produced for the export and domestic markets, respectively. In 2002, about $2000 \mathrm{mt}$ of black and $2000 \mathrm{mt}$ of green mung beans were supplied to the Lashkargah market. Most mung beans were sold by producers to grain and legume traders in Lashkargah soon after harvest (November-December). Net income to black mung bean and green mung bean production was estimated at Afgs 4500/ha and 8500/ha, respectively. Traders sold part of the beans in the winter but, in anticipation of higher prices, stored much of the mung beans through the winter and spring months. During these months, the traders suffered significant postharvest losses, with some traders losing $15 \%$ and others as much as $100 \%$ of their green mung beans to insect infestation.

With improved irrigation and higher rainfall in 2003, both black and green mung bean production is expected to be higher than in 2002 in Helmand. The price of black mung bean (currently Afs $4.4 / \mathrm{kg}$ ) in the Lashkargah market has historically been and remains significantly higher (20-80\% higher) than the price of green mung bean (currently Afs $2.5 / \mathrm{kg}$ ). If mung beans were dehusked and separated before marketing, the market prices for such products in domestic and international markets would be a number of times higher.

\section{Peanuts}

About $5000 \mathrm{mt}$ of peanuts were produced on about 1800 hectares of irigated land in 2002 . The farmers sold the majority of the peanuts in the Provincial markets and $500 \mathrm{mt}$ to CADG. CADG cleaned, selected, and distributed to farmers about $3.5 \mathrm{mt}$ of peanut seed for planting in 2003 . The average net income in 2002 for peanut production was estimated by CADG at Afs $28,770 /$ hectare. The breakeven cost of production has been estimated at about $360 \mathrm{~kg} / \mathrm{ha}$. If ridges are built for planting and irrigating the peanuts and weeding is done, peanut yields up to $1200 \mathrm{~kg} / \mathrm{ha}$ are possible. Over 12,000 hectares of peanuts are estimated to be under cultivation in 2003. The farmgate price of shelled peanuts is expected to range between Afs $17-22 / \mathrm{kg}$. Most farmers rotate peanut production every $3-4$ years.

A peanut oil press, located between Kandahar and Lashkargah, has been installed by CADG who will be buying peanuts from farmers in 2003.

\section{Cumin}

Since May, an estimated $360 \mathrm{mt}$ of white cumin have been supplied to the Lashkargah market by Helmand farmers. The relatively few traders who buy the cumin sell most of the cumin outside the Helman Province. Cumin is in high demand in Pakistan and India, however, the cumin needs to be cleaned and possibly powdered in order to fetch the high export prices.

\section{Melon and Watermelon}

Helmand has had a bumper crop of melons and watermelons in 2003. The yield ranges from 1500 to 2250 melons per hectare in fertilized fields where the black fly has been controlled. The 
price of melons has fallen from Afs 8000/wagon load (about 300 melons) in June to very near the breakeven price (about Afs 10/piece) of Afs 3000/wagon load in August. Most of the watermelons and melons are bought by traders in the Lashkargah market, transferred to $10-\mathrm{mt}$ trucks and then shipped to distant domestic markets.

\section{Tomato}

In Helmand, the bulk of tomatoes are produced and marketed fresh from June through October. In just the past two months, over $500 \mathrm{mt}$ of tomatoes have been estimated to have been supplied to the Lashkargah market. The glut has sent tomato prices down to a level below the cost of production. Excess supplies of tomatoes are typically dried and sold locally instead of being transported on poor roads to distant markets. Processing of tomatoes to ketchup remains an untapped alternative use. During the off season, very low volumes of tomatoes are imported from Pakistan.

\section{Tree Crops}

About $75 \%$ of Afghanistan's fruit tree orchards have been seriously damaged by drought, war, and environmental problems (Mercy Corps, 2003). Mercy Corps in Kunduz has established fruit nurseries, in a self-sustaining manner, with farmers in Helmand. In February, 2004, Mercy Corps will distribute an estimated 131,000 seedlings (almonds, plums, prunes, figs, peaches, nectarines, and apricots) for a fee to over 6,000 farmers who lost their fruit trees.

\section{Other crops}

Corn, sesame, grapes, pomegranate, and other vegetables, including eggplant, okra, cucumber, and onions were produced in Helmand. Of these crops, corn, grapes, and pomegranate were estimated to have relatively high net returns. Net income to corn, a cash crop mostly used for feed, was estimated at Afs $8000 /$ ha. High volumes of grapes are being supplied to the Lashkargah market. The excess grapes could possibly be dried into raisins or processed into juice. Pomegranate will be harvested later in the season during a narrow window of less than one month. The glut of pomegranates will be sent to distant domestic and export markets, though risking quality deterioration from transport on poor roads.

\section{Livestock}

The livestock market is relatively thin in Helmand. Cattle from Helmand are typically shipped by traders to Iran for slaughter, while cattle from Pakistan are imported by traders into the local market. Other types of livestock are traded mostly for local consumption.

The dairy industry once thrived in Helmand. However, much of the dairy herd has been decimated by war and drought. Many small milk and yogurt shops buy small quantities of milk from farmers operating near Lakshargah. Dairy herd development and dairy processing are possible opportunities for further investment. Helmand is a highly mechanized, highly irrigated province in Afghanistan. Although the agricultural sector has had a good production season, certain sub-sectors are having marketing problems. The marketing problems are exacerbated by the poor roads that make accessing distant markets difficult and expensive. The Helmand agricultural economy is closely linked to Kandahar and Herat as well as Quetta. 


\section{B.2 Participatory Rural Assessment of Local Markets}

A participatory rural assessment was conducted in the five most populous districts by a survey team from Helping Afghan Farmers Organization (HAFO) during August 5-10, 2003. Five villages in each district were randomly selected and the local shoura collaborated with the survey team to identify a group of knowledgeable farmer and trader assessment participants. The villages and their locations are shown in Figure 1. Each village PRA collected production and marketing data according to the format shown in Annex C. Village crop and livestock production data (crop land and livestock populations) were aggregated and projected to the district level by the ratio of district cultivated land area (from FAO estimates) to the cultivate land area estimated in the five PRA villages. Village agro-enterprise and population data were aggregated and projected to the district level by the ratio of district population (Central Statistics Office 2003 data) to the populations estimated in the five PRA villages. The five district projections were aggregated to create the summary shown in Annex C.

Figure 1. Location of Helmand PRA Districts and Villages, August 2003

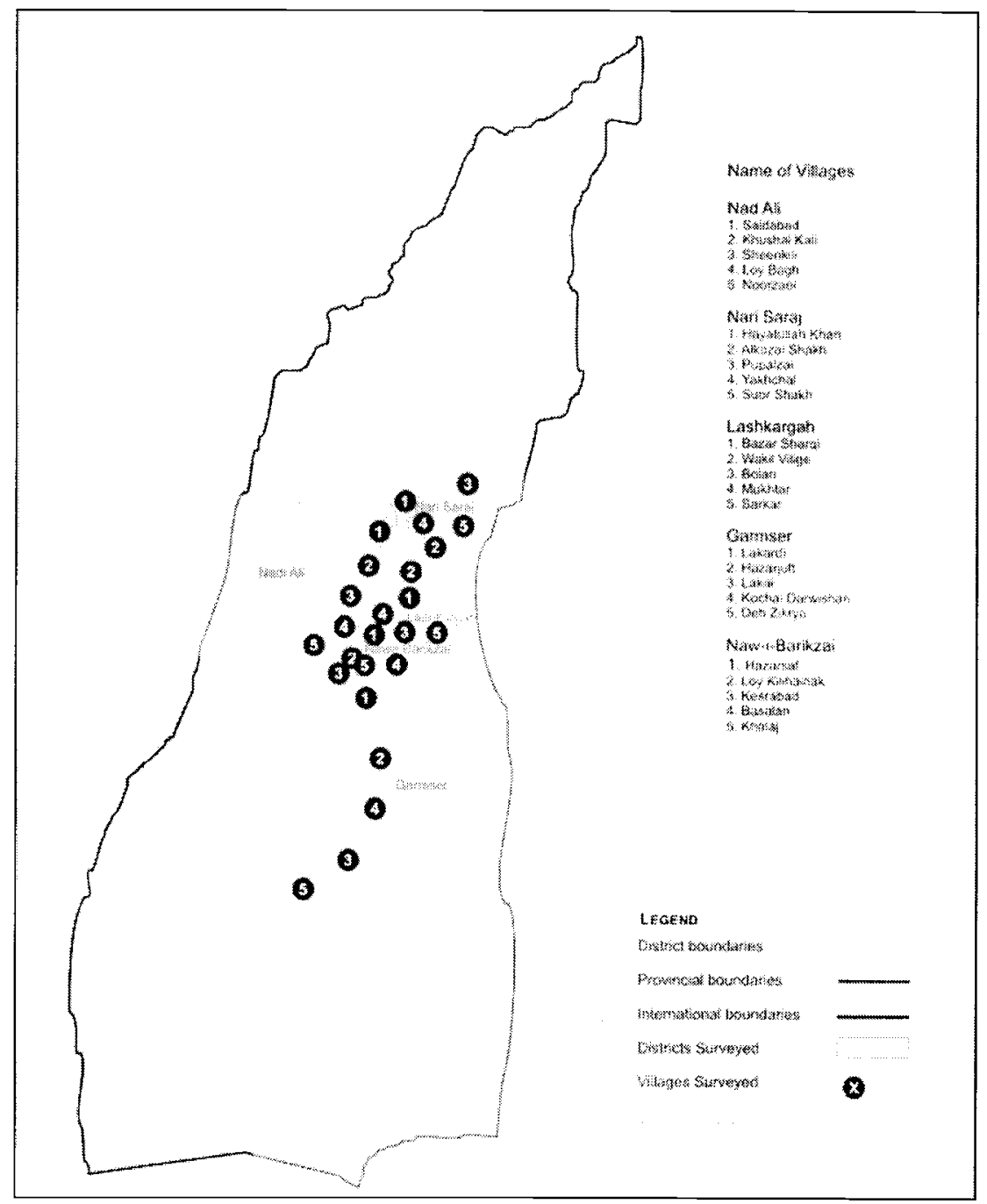




\section{B.3 Priorities of Helmand Beneficiaries}

The priorities of Helmand's beneficiaries (farmers, traders, processors, et.al.) include

- better access to improved seed for a variety of grains, legumes, and vegetables

- training and technical assistance in pest and disease control in, especially, wheat, cotton, melons, and vegetables

- training and technical assistance in storing grains and legumes, including storage pest control, grain storage facility selection and installation

- technical assistance in accessing and installing cleaning equipment for grains, legumes and cumin

- technical assistance in developing the feasibility of wheat milling

- technical assistance in dehusking, separating, and packaging mung beans

- technical assistance in accessing markets for cleaned cumin and dal from black mung beans

- access to credit for production, equipment, and machinery loans.

\section{Rural Financial Services}

\section{C.1 Current Conditions}

The Helmand Province is experiencing similar issues as the rest of the country with no access to formal financial services. The proximity of the province to Pakistan allows for cross-border trade although mainly for imported items. We took a different approach in Lashkargah by assessing the potential for small processing plants to increase the amount of goods made within Afghanistan. Of course, many policy issues regarding conditions and tariffs and doing comparative advantages of competitive products would be intertwined with continuing on this approach. One of the project aims will be to link rural goods and services to urban markets and demonstrate the profit potential of these sectors.

Hawalas do exist in Helmand but mainly serve as foreign exchange transactions or domestic/international payment transfers. It is unlikely that the hawalas would extend credit to RAMP's targeted beneficiaries.

There are limited private small and medium size enterprises (SMEs) with the biggest business of a state owned cotton ginnery in the province. We believe there are innovative micro and small businessmen who could develop new products and services for the local market beyond traditional entrepreneural activities. These businessmen are normally those who can take swift advantage of any opportunities in the market.

Discussions with a local tractor dealer selling Massey Ferguson tractors elicited ideas for them to enter some type of agro-processing business. They explained their interest in potentially entering the textile industry. They are profit driven and prefer to earn their profits rapidly. In the case of agro-processing, the breakeven point may take longer than their current business activities which could be a limitation. Also, they have concerns about the stability in the region before they would make an investment in a new venture. 
The overarching issue is the need for lasting peace and stability before Afghans are willing to invest in their country. They are willing to make less risky short-term investments but long-term investments are not common at this point. Both the political and economic instability in the country is deterring some investment inte agro-processing businesses. Also, the porous border of Pakistan may allow for the dumping of less expensive processed foods on the Afghan market. This occurrence would undermine the chance for Afghan-made products to survive unless the products are competitively priced and have a high quality standard.

As in Kunduz, there is a women's resouce center in Lashkargah which provides six month courses in tailoring, literacy and the English language. The center is also planning for computer courses in the next few months after receiving donated computers. The head of the center had a long list of needs that she hoped would be provided to the center including sewing machines, fabric for the trainees to practice sewing, a market for their goods, computers, branches in the villages and other items. CADG has assisted the center in rehabilitating their building and with the English language courses. Mercy Corps has also provided assistance with some sewing machines and other materials.

The women expressed an interest in starting some home-based income generating activities upon completion of their courses. Some of the identified activities include tailoring, raising chickens and bakeries. Carpet weaving is not prevalent in the region as there are few ruminant livestock for making the wool. Some of the women are widows and need a source of income. Also, there are children of female inmates who need to be assisted.

There was little evidence of any pre-formed groups or associations within Helmand as compared to the groups we met in Kunduz. Through CADG, there is a strong network of extension agents throughout the province. Also, the Ministry of Agriculture has a small cadre of extension agents. Based on a survey completed by CADG, there are over 3500 tractors in the province. They were not aware of any tractors in disrepair. Nor were the Massey Ferguson dealers aware of any tractors which were inoperable. As part of the proposal from the Massey Ferguson distributor, a need was expressed for the repair of damaged tractors to return them to the use of the farmers. Further details of this need will have to be demonstrated before this part of the proposal would be accepted.

Upon discussions with CADG extension workers, farmers and some grain dealers, there was a an expression for credit access to support plans for building storages, buying seed and fertilizer and small processing equipment. Some of the equipment needs included cotton gins which sell for approximately $\$ 600$ and peanut oil presses which sell for between $\$ 5000$ and $\$ 30,000$. Also, loans could be used for multi-purpose and cold storages, dehusking machines and dairy processing equipment. The women expressed an interest in buying sewing equipment which sell for approximately $\$ 40$, chicken rearing which could be started as little as $\$ 20$ for 10 chickens and bakeries (no price estimate on opening a bakery).

A local radio station is located in Lashkargah. Through this medium, RAMP and our partners could announce news about rural financial services.

Of the wholesale agro traders we interviewed, none of them had ever had a credit with the Agricultural Development Bank as they understood that the bank only provided credit to farmers. We tried to meet the Credit Specialist at the Agricultural Development Bank but he was out of the country during our visit. 
The Managers of Mercy Corps were not available in Lashkargah for a meeting. We did meet with Keith Polo, the Agriculture and Livelihoods Specialist, who is based in Kandahar previous to our visit to Helmand.

\section{C.2 Priorities of Helmand Beneficiaries}

The priorities of Helmand's beneficiaries (farmers, traders, processors, et.al.) include:

- better access to credit, particularly for investment in improved seed processing and storage facilities

- access to working capital for traders' inventories of inputs and farm products is needed to be more responsive to seasonal market conditions

\section{Infrastructure Rehabilitation}

\section{D.1 Current Conditions}

Irrigation: Due the prolong war in the country the irrigation infrastructures have been destroyed severely and needs urgent rehabilitation.

- In Nad-e-Ali ,Nawa-e-Barakzai and Marja canal and drain systems needs more cleaning in order to irrigate the farmers fields properly. $50 \%$ of the cleaning is done and the remaining $50 \%$ should be cleaned.

- Some drops, intakes retaining walls need to be rehabilitated and restructured in Boghra and other places.

- Cleaning of some Karezes in north and east part of the province for securing water for irrigation.

Infrastructures rehabilitation: The president of MRRD explained that before the war extra products of Helmamd province such as wheat, barley maize ,peanut, mung bean water melon were transported by the traders to Kandahar, Kabul ,Urozgan, Ghor and other areas of the country. But now due to the destructions of the roads it is very hard to take the extra products to the other places.

Also the roads of the districts to Lashkergah has been seriously damaged. They need levelling, gravel application and side ditches to be repaired. They mentioned in some of the roads from districts to Lashkergah only the tractors can transport the commodities, it is not possible by the cars and trucks.

Currently, the Old Shamalan and New Shamalan Canals are full of mud and silt, preventing water flow, leading to a shortage of irrigation water. Some gabion works are needed for river protection. The lack of irrigation sources is resulting in lower yields and therefore lower incomes for farmers. 
The Old Shamalan Canal has a great importance for agriculture in Helmand. The canal is $37 \mathrm{~km}$ long and is the main source of irrigation for more than a quarter million jiribs of land. Approximately 45,000 families' farming productivity would be positively impacted by cleaning this canal.

The New Shamalan Canal also is an important part of the irrigation system in Helmand. The New Shamalan Canal is $26 \mathrm{~km}$ long and is the main source of irrigation for more than 180,000 jiribs of land. Approximately 30,000 families' farming productivity would be positively impacted by cleaning this canal.

Under current conditions, only $60 \%$ of this land is being cultivated. With proper cleaning and some minor repair, land under cultivation would increase to $100 \%$. Additionally, only a few farmers along these canals are able to double crop, whereas most farmers would have the capability to double crop after rehabilitation of the canals.

\section{D.2 Priorities of Helmand Beneficiaries}

The priorities of Helmand's beneficiaries (farmers, traders, processors, et.al.) include

- Urgent rehabilitation of irrigation canals and drainage serving 100,000 to 150,000 hectares of cultivated land, with particular emphasis on the Shamalan canals;

- Improved on-farm irrigation management

- Improved maintenance of irrigation canals, intakes, drains and canal-related roads

- New community-based market centers, to concentrate produce for distribution in district and regional market centers 
REBUILDING AGRICULTURAL MARKETS IN AFGHANISTAN PROGRAM (RAMP) 


\section{A. Agricultural Technology and Market Development}

Farmers in Helmand have had problems in accessing good quality seed, controlling pests and diseases, storing grains and legumes, and accessing markets for their products. For the agricultural sector to advance and for farm family incomes to be increased, the Lakshargah to the main highway from Kandahar needs to be improved; better access to improved seeds of the staple crops and high value crops need to be made; farm plots demonstrating production of improved varieties of the major crops need to be established; irrigation infrastructure needs to be rehabilitated; grain/legume storage facilities for both farmers and traders need to be identified and installed; credit opportunities need to be made available for production inputs, storage, processing, and marketing agricultural commodities; processing of grains, legumes, vegetables, and fruits need to be promoted; private cotton gins should be allowed to operate; animal health laboratories, vaccines, and veterinary services need to be made readily available to the livestock industry, and an artificial insemination program needs to be implemented.

\section{B. Rural Financial Services}

Based on the economic activities within the Helmand area, our assessment concluded that our efforts should be concentrated on increasing the processing of agricultural products. The province lends itself to this evolution from merely trading agricultural products due to the overall level of agricultural outputs in the region and the opportunity for substituting imports. These small and medium producers need to be strengthened, improved and have increased access to finance. These producers can have a major impact on private sector employment opportunities for Afghans. Access to credit will have a multiplier effect on the borrowers, employers and the market.

CADG has demonstrated success in agro-processing and has made strides in finding export markets for items such as raisins. They plan to expand their processing capabilities and RAMP can tap into their strategic plans to have impact on the agricultural sector. Also, they have a province wide extension agents network which could be utilized to identify potential clients.

MFIs should be readily accepted in Helmand as suppliers of credit. The MFIs will have to test different methodologies - group lending, individual lending, village bank lending, or credit unions - to determine which is most suitable for the projected borrowers.

Technical assistance may be needed for the MFI to reach the agricultural sector. Any loan methodology targeted to women should initially be introduced to the local leaders, husbands of borrowers and/or mullahs. Helmand is a very conservative area and acceptance by these male leaders will work to the benefit of the MFIs.

The assessment team identified agricultural products which could be cleaned, processed or stored and with processing would bring additional value to the item. Each of these steps will require some amount of capital investment from the entrepreneur. Based on our interviews, some entrepreneurs are ready to invest their own capital for these value added processes. Their capital may need to be leveraged with credit from a financial institution to meet the overall expense for some of the necessary fixed assets. 
RAMP could consider structuring some sort of debt and/or equity instrument specifically for agro-processing businesses. This type of business investment could jump-start the agro-processing sector, increase the capacity within the industry, provide employment, raise the overall level of agricultural outputs for the region and replace some foreign imports. Furthermore, RAMP's investment could have a demonstration effect and attract other investors to the province.

The form and details of this type of equity partnership would need to be negotiated between all parties involved. Transfer of ownership or a buy-out of RAMP shares would have to occur before the end of the three year program. An agreement would have to detail the level of equity ownership, the rights of the owners, the buy-out terms, etc. The terms should be written in such a manner that the equity investor, the ultimate owners and the beneficiares all receive equitable benefits.

Along with the availability of credit for these agro-processing enterprises, RAMP will need to simultaneously work with appropriate ministeries and other USAID contractors on the legal and regulatory framework and economic and trade policies. Although the extension of credit or equity investments should not be delayed while perfecting the collateral laws, foreign investments laws, etc. some initial funding can begin to inject capital into the market concurrently with the implementation of these laws.

CADG has made an impact on poppy irradication. RAMP can build on the efforts made to date by promoting the legal economy through developing market structures and providing credit to agro-businesses as an alternative to poppy growing. These efforts can have a tremendous impact on economic stabilization for the province.

Dual currencies, Afghani and Pakistani Rupee, circulate in parallel in the province. Financial institutions will need to consider their choice of currency when lending. There are very few national or international NGOs working in the Helmand area. The security of the area has filled NGOs with apprehension about the issue of stability. Those that are in the area such as Mercy Corps and CADG could act as a reference for the character of their beneficiaries who want access to credit. These organizations can indicate their capability to repay to the financial institutions.

The RAMP assessment results from both Helmand and Kunduz provinces bear out similar responses as the microfinance feasibility studies conducted by World Bank, IPC and Horus Banque et Finance

\section{Infrastructure Rehabilitation}

The Hemand irrigation system is a vital part of the national economy, but the political instability of the last 25 years has left the system in serious disrepair. From the onset of construction, the emphasis was on adding canals, with little regard for the importance of drainage. Within three years after the initial canals were put into operation, the water tables rose to within 12 to 18 inches of the surface over wide areas of the system. The resulting rise in salinity essentially offset the initial benefits of irrigation.

Rehabilitating the system will require major silt removal and intake repairs along most canals, with simultaneous cleaning and repair of the drains for those respective canals. A 
detailed assessment will be required to plan and coordinate the overall system renovation so that each successive job order addresses the water supply and drainage requirements for a contiguous command area.

The large scale of irrigation rehabilitation requirements dictate that the work be completed as quickly as possible, to minimize disruptions to nearby command areas, expedite the return of cultivated lands to full productive potential and minimize exposure of work crews to a growing insecurity situation. This means the canal cleaning operations will have to emphasize mechanical methods, using draglines and articulated dredges.

Rehabilitation of the irrigation system will not realize full productive potential of the affected cultivated land without at least four concomitant interventions:

1. improved farm-to-market roads, particularly links to the Kandarhar-Herat highway;

2. a sustainable road and irrigation maintenance system that is consistent with the region's economic contributions to the national economy;

3. improved on-farm irrigation management; and

4. privatizing the cotton processing industry. 
REBUILDING AGRICULTURAL MARKETS IN AFGHANISTAN PROGRAM (RAMP) 


\section{SECTION IV - ASSESSMENT RECOMMENDATIONS}

\section{A. Agricultural Technology and Market Development}

To advance the agricultural sector and improve agricultural incomes and marketing opportunities, the following is recommended:

- The road from Lashkargah to the main highway linking Kandahar needs to be improved

- To assist farmers in identifying the quality of seed they need for increasing productivity of grains and legumes, extension agents of CADG and the MAAH in Helmand need to be trained

- Private seed multiplication efforts by farmers assisted by Mercy Corps and CADG need to be further supported

- Farmers need to be trained in the use of agricultural chemicals on their crops.

- At least one demonstration plot needs to be established in each cluster of villages in all Districts to show farmers the production potential of improved varieties of major crops, such as, wheat, rice, and maize

- Provide water control and management training to mirabs responsible for extensive irrigation schemes

- Provide technical assistance to farmers interested in installing greenhouses for vegetable production in the off season

- Farmers and traders need training in grain postharvest storage and handling. Grain storage (and drying) facilities that match the needs of farmers and traders need to be identified and installed before the bulk of the rice is harvested

- Grain, legume, and cumin cleaning and sieving equiment for farmers and traders need to made available on a custom basis

- Technical training of farmers, traders, and mill operators is needed in wheat grading using a sampling mill and other mechanical devices

- The feasibility of modular wheat milling technologies, such as the Kice mill, needs to be made; if deemed feasible, investors for the milling equipment need to be identified

- Detemine the feasibility of peanut oil pressing and tomato ketchup processing

- Equipment for dehusking and separating mung beans for increasing the value of the beans need to be identified and the feasibility made

- Advocate for eliminating the government policy that limits cotton ginning to government owned gins

- Establish private nurseries for vegetables, tree crops, and other trees for reforestation

- Determine the feasibility of installing animal health laboratory facilities in the private sector

- Train and certify para-veterinarians in animal health, including vaccinating, disease and parasite control and treatment measures

- Establish an artificial insemination program through the MAAH and the para-vet program 


\section{B. Rural Financial Services}

The following recommendations are made for improving financial services in Helmand:

- RAMP promotes the intervention of a broad range of financial services to the agricultural sector. Local and international financial institutions will take a role in shaping the economy in Helmand. Again as in Kunduz, RAMP will look to MISFA, new commercial banks in Afghanistan, investors and other donors to consider Helmand as a vibrant area for micro, small and medium agricultural based enterprise activities. As there is not a financial institution available to provide any level of financing for the agricultural sector, it may warrant some novel interventions such as the following.

- Similarly to Kunduz, RAMP will coordinate with MISFA to invite any of the pre-selected microfinance institutions (MFIs) -- Aga Khan, AREA, BRAC, CARE, CHF, FINCA, Mercy Corps, SCF, WOCCU, WfWI - to work in Helmand province. Mercy Corps is already working in Helmand and may be able to augment their current agricultural projects with microfinance activities. If Mercy Corps chose to extend credit, their agricultural services would need to be separated from any lending activities. Any existing organizations in Helmand, such as CADG, could provide character references of their beneficiaries to the MFIs. This would assist the MFIs in selecting credit worthy borrowers.

- RAMP will need to review with USAID the possibility of partnering with some entrepreneurs to create new agro-processors either directly or through a financial institution. This could be considered as a public/private partnership whereby RAMP could support the agro-enterprise with some funds, possibly an equity or quasi-equity investment, as a first phase. The second phase would be an agreement to buy-out the RAMP shares by the owners or other investors before the end of the three year project.

- Another partnership which RAMP could explore is through new commercial banks entering the Afghan market to support agro-businesses. The banks will most likely want to share the risks in delivering financial services to this sector based on the vulnerability of the environmental conditions. A methodology successfully used in other countries would be for a non-bank financial institution to coordinate through a commercial bank to lend to small and medium enterprises. This intervention could be designed such that the financial institution would identify the clients, underwrite and service the loans and present them to the bank for approval. As an alternative, RAMP could provide a credit line to the bank specifically for loans to the agricultural sector and the bank would be responsible for the entire loan process.

- Another form of investment could come from external investors. RAMP could open dialogues with investment firms such as the Afghanistan Investment Support Agency (AISA) and attract investors to the agricultural focal areas of Helmand. AISA will be searching to identify potential investors from the Afghan diaspora and the European community to invest in profitable ventures in Afghanistan.

- CADG will be making contacts with other investors. RAMP could collaborate with these potential investors to build the agro-processing sector.

\section{Infrastructure Rehabilitation}

The following recommendations are made for rehabilitating infrastructure in Helmand: 


\section{ANNEX A - PERSONS CONTACTED IN HELMAND}

\begin{tabular}{|l|l|l|}
\hline$\#$ & Name & Title \\
\hline 1 & Haroon Agha & Massey-Ferguson Tractor Dealer \\
\hline 2 & S. Amunulth Satad & President, Laskhargah Radio Station \\
\hline 3 & Md. Azim & Grain Dealer and Flour Miller \\
\hline 4 & Salim Khan & Watermelon Dealer \\
\hline 5 & Haji Md. Shereen & President, Bust Company (cotton gin) \\
\hline 6 & Gulam Nabi & Head of Improved Seed Company \\
\hline 7 & Gulam Habib & Director, Agriculture Department \\
\hline 8 & Abdul Samad Bayik & Deputy Director, Agriculture Department \\
\hline 9 & Faiz Mohammad & Director, Agricultural Extension Department \\
\hline 10 & Gul Dad & Director, Animal Husbandry Department \\
\hline 11 & Gulam Nabi & Director, Rural Development Department \\
\hline 12 & Engineer Shakir & $\begin{array}{l}\text { DAI Helmand Manager, Assisting Afghanistan to } \\
\text { Revitalize Irrigated Agriculture Project }\end{array}$ \\
\hline 13 & Engineer Rahmathllah & CADG Country Director \\
\hline 14 & Jeff Paine & CADG Finance Manager \\
\hline 15 & Abdul Gami Aubi & CADG Bolan Experimental Farm Manager \\
\hline 16 & Engineer Sharajudin & CADG Helmand Engineering Department \\
\hline 17 & Jamal A. Naser & CADG Agricultural Officer in Charge \\
\hline
\end{tabular}


REBUILDING AGRICULTURAL MARKETS IN AFGHANISTAN PROGRAM (RAMP) 


\section{Helmand Province \\ Department of Agriculture \& Livestock \\ General Directorate of Liaison}

August 13, 2003

\section{To: The Ministry of Agriculture and Livestock}

In respect to the Ministry letter number 812 dated $19 / 5 / 1382$ replying as follow;

A delegation from various institutions headed by Mr. Mohammad Nazir representative of the Ministry of Agriculture has come to the Helmand Province and they established a large gathering in connection with the above-mentioned letter. The meeting was held on 20/5/1382 in the General Department of Agriculture and Livestock participated by the heads of Agriculture, Irrigation and Rural Development and they discussed the related issues in very details. The main key problems as well as the needs of the area were clearly identified. It is worth mentioning that the Helmand Province is the major agriculture producer for assorted grains of the country. In the past, it was nominated as a Godown (store) of food. The climate of this province is very much feasible for double agriculture production in one year. I regret to say that the public welfare agriculture sources, irrigation channels, water drainage canals' including transportation routes of the region has been severely damaged by war during the past two decades. Undoubtedly, the war effected on the reduction of agriculture and livestock production as well as a negative affect on the interior and foreign food market price. The Islamic Transitional Government of Afghanistan has no resources for the reconstruction/rehabilitation of the listed below projects.

Therefore, there is urgent need for the support and assistance of the international organizations especially RAMP - USAID to assist us in the rehabilitation of the following projects.

\section{Research and Agriculture Research Services.}

- Rehabilitation of 33 residence/office buildings at different locations within the province,

- 10 vehicles

- 10 motorcycles

- 10 bicycles

\section{Livestock Project - Livestock Research and poultry farm}

- Rehabilitation of livestock farms

- Reconstruction of 10 poultry cages

- 100 milk cows

- 10 generation Oxes

- 5 tractors with complete components for for 65 hectares livestock farm land

- 2 poultry incubators with capacity of 2500 eggs.

- 3 vehicles

- 10 motorcycles

- 10 bicycles 


\section{Plant Protection Department}

- 2 Microscopes

- 2 vehicles

- 5 motorcycles

- 5 bicycles

- Various medicines for agricultural insects

\section{Bolan Agriculture Investigation Farm required the following;}

- 10 Tractors with all necessary components for the preparation 250 hectors of land on two farms including tools and equipment such as are shovels, picks, sickle etc.

- Seeds such as is cotton, corn, and mung bean, vegetable, fertilizer as needed

- Wheat seed distributor

- Seed cleaner

- Other tools and equipment for cotton and corn cultivation

- 3 vehicles

- 6 motorcycles

\section{Department of Veterinary and Artificial Insemination:}

- Tools and equipment for artificial insemination

- Medicine for livestock diseases

- 3 vehicles

- 5 motorcycles

- 2 Microscopes

\section{General Department of Forestry and environment:}

- 2 Tractors with all components

- 2 vehicles

- 7 motorcycles

- Forestry tools

\section{Fertilizer Incumbent:}

Before war, the above Incumbent was maintaining sufficient fertilizer and variety of medicine of anti-agriculture and vegetable diseases and insects. They were selling these items to farmers on credit as well as in cash to meet farmers' requirements. At present, the department is in urgent need of 20,000 tons of fertilizer and 5 tons of different kind of medicine for agriculture diseases.

\section{Agriculture Cooperation Section.}

- 2 vehicles

- 5 motorcycles

- Construction of cooperation building including office furniture and equipment.

\section{Agriculture Equipment Workshop}

Before war the Agriculture Repair Workshop was fully equipped and a total of 45 agriculture tractors were getting repair in this workshop. However, at present its building has been completely destroyed.. It is needed that the workshop should be re-established. 


\section{Irrigation Project:}

The plan for the water irrigation system has been prepared and submitted to the ministry

\section{Rural Development Project:}

The rural development project plan has been prepared and submitted to concerned departments in four pages.

The above work plan of the Irrigation Department (one page) and the work plan of Rural Development (4 pages) has been submitted to you and we hope that you will pay special attention for the rehabilitation and reconstruction of the above-mentioned Agriculture and Livestock, Irrigation and Rural Development projects.

We request you to encourage the donor agencies to contribute their support for the implementation of these urgent projects in the Helmand Province which are significant in promoting the economic standard of farmers and for the evaluation of agriculture production in the country.

Signed by: Governor of Helmand Province. 
REBUILDING AGRICULTURAL MARKETS IN AFGHANISTAN PROGRAM (RAMP) 


\section{ANNEX C - SUMMARY OF PARTICPATORY RURAL ASSESSMENT}

(Projected Total for 5 Districts: Nad Ali, Gamser, Naway I Barakzayi, Nahri Sarraj, and Laskargar Center)

\begin{tabular}{|c|c|c|c|c|c|c|c|c|}
\hline $\begin{array}{l}\text { 1. Agriculuiral Production } \\
\text { and Sales lndicators } \\
\text { Non+wy Crops } \\
\text { Eafoy }\end{array}$ & Jartess & Tons & $\begin{array}{l}\text { Yold } \\
\text { (knjtes }\end{array}$ & $\begin{array}{l}\text { Yoid } \\
\text { Tonswit }\end{array}$ & $\begin{array}{c}\text { Fum Fine } \\
\left.\operatorname{lat} x_{0}\right)\end{array}$ & $\begin{array}{l}\text { Production } \\
\text { Volue } \\
\text { Al } 000\end{array}$ & $\begin{array}{c}\text { 3ol } \\
\text { Produclion } \\
\text { Warketad }\end{array}$ & $\begin{array}{l}\text { Markolud } \\
\text { Valat } \\
\text { Ar noo }\end{array}$ \\
\hline Gotion & 40.358 & $13,40 \%$ & 332 & $1.0 \%$ & 9.30 & 152,898 & 100 & 153,658 \\
\hline Maras lower Pols & 100,572 & $43 \mathrm{css}$ & 416 & 2010 & 4.13 & 177,867 & 70 & 124270 \\
\hline Milw & . & . & . & . & - & . & . & \\
\hline Ruce & - & & . & . & - & . & . & \\
\hline What & 303.221 & $\$ 48,170$ & 40 & $2+4$ & 5.25 & 772,70 & 39 & 304,321 \\
\hline Tatal Non-HV Grops & 466651 & 207,675 & 4 Sis & $2 \times 27$ & 636 & 1,10589 & 53 & 583,098 \\
\hline 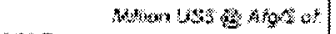 & 48.80 & & & & & $23: 135$ & $s$ & 12148 \\
\hline $\begin{array}{l}\text { HV Crops } \\
\text { Vegetables }\end{array}$ & & & & & & & & \\
\hline $\begin{array}{l}\text { Ecar frowh } \\
\text { Bcar rother woul }\end{array}$ & $\begin{array}{r}3,320 \\
11,332\end{array}$ & $\begin{array}{r}351 \\
234\end{array}$ & $\begin{array}{l}117 \\
113\end{array}$ & $0.5 \%$ & 8.30 & $\begin{array}{r}3.825 \\
13.120\end{array}$ & $\frac{9}{72}$ & $\begin{array}{l}3.373 \\
9.400\end{array}$ \\
\hline Brondfow mast. & - & $\cdot$ & $\cdot$ & * & * & 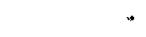 & * & . \\
\hline calbuge & - & . & & " & * & + & . & • \\
\hline Carulillowews & - & - & - & - & - & - & - & • \\
\hline chll & - & - & - & * & - & + & - & $\because$ \\
\hline Cosutntser & 9020 & 16.507 & 1073 & $\$ .38$ & 0.1 & 11,345 & 75 & 8,498 \\
\hline Esoptant & 2,139 & 50 & 228 & 1.13 & 2.47 & 1.242 & 36 & 447 \\
\hline Gathe & - & " & $\cdot$ & •. & $\cdot$ & . & .. & . \\
\hline Ginger & $\cdot$ & - & " & " & $\cdot$ & - & - & - \\
\hline Green osa & - & · & & . & . &. & . & • \\
\hline Aalict (Wybrids? & - & - & $\therefore$ & 4 & 0.72 & 21,703 & $\dot{8}$ & : \\
\hline Merion & 27,627 & 30,130 & 1,190 & $\$ .45$ & & & 78 & 16.42 \\
\hline Hedors Wolver & 30,276 & 44,000 & 1.213 & 6.08 & 0.23 & 10.213 & 58 & 3.901 \\
\hline Okra & 3.35\% & 2112 & 225 & 1.2 & 0.97 & 2,040 & 47 & 959 \\
\hline Onion & 2.954 & 4264 & 1.44 & 7.22 & 1.90 & 2000 & 82 & 6,600 \\
\hline Oma loaly wey. & 1790 & 3075 & 1,731 & 2.65 & 1.01 & 3.115 & 41 & 1231 \\
\hline Potatu & * & - & - & * & * & - & * & . \\
\hline Pumplan & • & - & - & * & * & - & . & - \\
\hline Aation & 131 & 3 & 400 & 2.28 & 1723 & 1,013 & 80 & $\$ 10$ \\
\hline $\begin{array}{l}\text { Tombio } \\
\text { carrot }\end{array}$ & 5.601 & 3.787 & 310 & 1.55 & 1.24 & 2.186 & 75 & 1.634 \\
\hline Trarmep & - &. & . & - & - & - & . & . \\
\hline Zagher & - & . & . & - & - & - & - & . \\
\hline Curnin & 428 & 284 & 64 & 0.52 & $113 \mathrm{u}$ & $4,9 / 4$ & 98 & Ants \\
\hline Pa Nuts & 7,832 & $4+40$ & $5+3$ & 2.7 & 14,43 & 61,322 & 100 & 51,322 \\
\hline Opium Fopy & 6.902 & $15:$ & 18 & 0.00 & 2.471 .34 & $282: 557$ & 100 & 302057 \\
\hline \multicolumn{9}{|l|}{ Egurrums } \\
\hline Buxikyar: & - & -. & - & * & * & - & . & . \\
\hline Atrosen & $60.1 \%$ & 15.27 & 170 & Q.t. & 1428 & 21966 & $\pi$ & 160.988 \\
\hline 2entil & $\cdot$ & · & 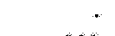 & $\cdot$ & - & $\therefore$ & - & - \\
\hline Dheopar & 242 & 64 & 285 & 1.33 & 1100 & 706 & 95 & 870 \\
\hline Soyotan & " & " & - & - & - & $\cdot$ & . & " \\
\hline Edble ots & 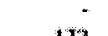 & & & $\cdot$ & - & & & \\
\hline Austare Seed & 19 & $\pi$ & 4.4 & 2.22 & 17.70 & 1,350 & $\$ 0$ & 1,223 \\
\hline Olise: & - & - & * & " & • & * & - & . \\
\hline Satlower & - & - & $\cdot$ & - & - & - & - & - \\
\hline Suntlexwe? & $\cdot$ & $\cdot$ & $\cdot$ & - & - & $\cdot$ & • & • \\
\hline \multicolumn{9}{|l|}{ Fruits } \\
\hline $\begin{array}{l}\text { Aprols: } \\
\text { Apricot }\end{array}$ &. & . &. & - & : & - & - &. \\
\hline $\begin{array}{l}\text { Aprical } \\
\text { chetryy }\end{array}$ & - & . &. & - & . & 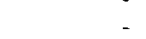 & - &. \\
\hline ondaty & 3.540 & S. 183 & 1.477 & 7.39 & 11.25 & $\$ 2,008$ & 72 & 08,480 \\
\hline Srapen, Fasin & . & & & . & . & $*$ & 。 & . \\
\hline Mubetry & • & " & - & -. & . & - & & . \\
\hline Peacto & 134 & 5 & 450 & 225 & 5000 & 353 & $\mathrm{Ba}$ & 222 \\
\hline Poat & $\approx$ & - & - & - & - & · & . & . \\
\hline Puam & $\mathbf{s}$ & 2 & 450 & 2.25 & 5.60 & 11 & 60 & 7 \\
\hline Porneguature & 1.31 & 154 & 1.170 & 5.50 & 10.90 & 10,972 & 72 & 12237 \\
\hline Nuts & & $\cdot$ & & & & - & & - \\
\hline Af ansand & - & $\cdot$ & $\cdot$ & - & $\cdot$ & - & 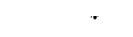 &. \\
\hline Pintactio & - & 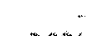 & · & $\therefore$ & : & $\therefore$ &. & .. \\
\hline Watimut & 1007 & 3.324 & 380 & 195 & $4 \mathrm{so}$ & 50.875 & 101 & 57.083 \\
\hline Tohal WV Crogs & 240,757 & 136,191 & 593 & 2.90 & 8.37 & 657,957 & 98 & 764.457 \\
\hline 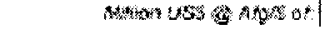 & 48.00 & & & & $\$$ & 18.082 & & 15.928 \\
\hline
\end{tabular}


Annex C - Summary of Participatory Rural Assessment (continued)

\begin{tabular}{|c|c|}
\hline 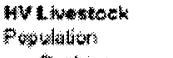 & Novatuse \\
\hline 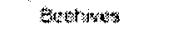 & • \\
\hline Onkekt som. & . \\
\hline Qumsen, twi & $38: 227$ \\
\hline$\varnothing \infty$ & 14048 \\
\hline Geant & 5,300 \\
\hline $\begin{array}{l}\text { Showe } \\
\text { Ground forato }\end{array}$ & 100,132 \\
\hline
\end{tabular}

8,98

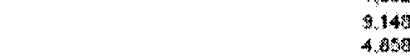

Procuction

Alat

Ecos

Chickun. wom

criwknn, ns.

Gous:

some

4.060

Eq

Crickut. wom

Carknii. rui.

被k

Pon

Towis

Fathon

Fistludion

salaie

(a) An wor

Totis

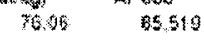

$\$ 00$ करत $2518 \%$

$\begin{array}{lll}400 & 528 & 2510 \\ 405 & 987\end{array}$

$5 \% \quad 1 \% 458 \quad 53506$

2.587 66.40 222,407

000

\{alkat?

222,487

$50.2 \%$

\$. 376

Torm

21,453

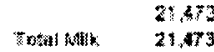

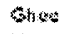

Mrans

$\$ 28$

Grand istage (we)

1. 274055

$2.37 \quad 213.052$

(w)andt)

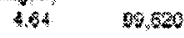

ankg?

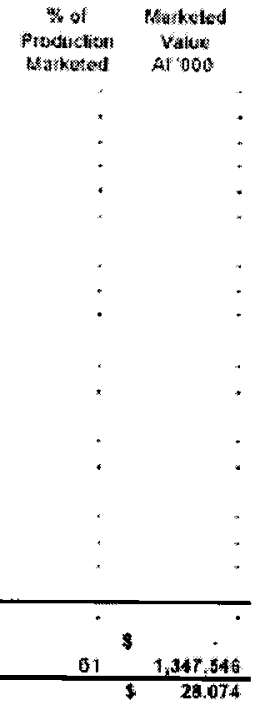

1. Aulinm Les Alos at

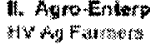

34:

Fxmilo

Wh an Trates?

Bnall

axpo

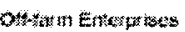

Micio

Sinisill

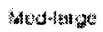

11. Populution, Land,

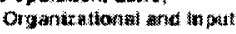

Suppliar indilestors.

Partwation

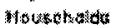

His ours

vatustos

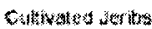

sis

i) ntand

Anrual 7.105

Ferantiol $\begin{array}{r}4122 \\ \text { Texal }\end{array}$

Tans

34.

(atsis

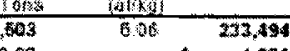

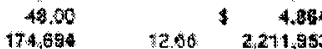

473

2. $50 \quad 2,211,853$

46.082

2074

Noxisan

33.022

33.02

Nuthber of Femalio

$37 \% 9$

3,79

Numtua 9 somale

255

(Snititis mpleys 3-9 woikers)

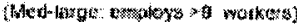

258

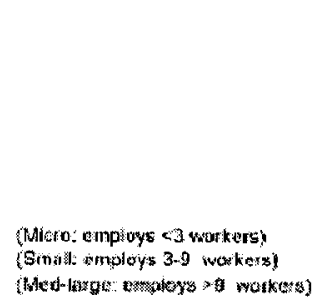

Nistuber

401204

54,36

7.25

150

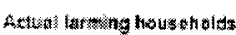

Nov

68.4

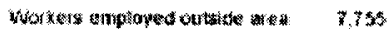

375.505

375.005

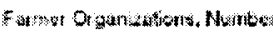
Male Mentuers

Fenda Mambers

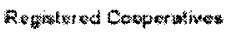

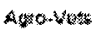

andoen Haw 


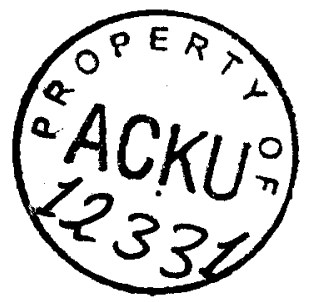

